\title{
Tanzanian mushrooms and their uses 2. An edible species of Coprinus section Lanatuli
}

\author{
MARJA HÄRKÖNEN, TIINA SAARIMÄKI and LEONARD MWASUMBI
}

\begin{abstract}
HÄRKÖNEN, M., SAARIMÄKI, T. \& MWASUMBI, L. 1993: Tanzanian mushrooms and their uses 2. An edible species of Coprinus section Lanatuli. - Karstenia 33:51-59. ISSN 0453-3402

Coprinus cinereus s. lat. is commonly grown in waste heaps of sisal (Agave sisalana) processing factories in Tanzania. The local people utilize the fungus as a food crop all the year round. The taxonomic status of the Tanzanian Coprinus population needs further study.

Key words: Africa, Coprinus, edible mushrooms, ethnomycology, sisal, Tanzania

Marja Härkönen and Tïna Saarimäki, Department of Botany, P.O. Box 7, FIN-00014 University of Helsinki, Finland

Leonard Mwasumbi, Department of Botany, University of Dar es Salaam, P.O. Box 35060, Dar es Salaam, Tanzania
\end{abstract}

\section{Introduction}

This article is part of a series of studies dealing with Tanzanian edible mushrooms. For the background, methods and research area of the project see Härkönen (1992) and Härkönen et al. $(1993 a-c)$.

During our expeditions in Tanzania we were told several times that edible mushrooms grow on sisal Agave sisalana waste near sisalprocessing factories. In November-December 1991 we made special trips to three sisal plantations in three different districts.

\section{The cultivation of sisal in Tanzania}

The sisal fibre produced from Agave sisalana is of great commercial value in Tanzania. According to statistics (FAO 1991), Tanzania exports about $9 \%$ of the world's sisal fibre, which is $19 \%$ of African production; it is the second producer in Africa after Kenya. In Tanzania sisal fibres make up $26 \%$ of the agricultural export and $16 \%$ of the country's total export. Sisal fibre is used for making parceling twines, ropes, sackings, carpets and upholstery.
Agave originates from Central America. Agave sisalana was introduced to Tanzania (Tanganyika at that time) in 1891 by Dr. Hindorf (Lock 1969). He ordered 1000 bulbils from Florida plant suppliers, but only 62 bulbils survived. These were planted in the dry plains of the Tanga hinterland. They formed the foundation of the sisal industry in East Africa. Subsequently, more bulbils were ordered directly from Mexico. Because sisal cultivation in Tanzania was influenced by transport communications, a group of sisal plantations lie along the Tanga railway line. Another centre for sisal plantations is the railway line from Dar-esSalaam to Morogoro and Kilosa. The third centre includes Lindi and Mtwara in the southeast. In addition there are some isolated plantations in the Lake and Western Provinces.

A sisal plantation produces a steady supply of leaves all the year round. The harvesting of a sisal plant can begin between the age of 2-4 years, and can be continued twice a year for several years. Cultivation involves intensive human labour. The undermost leaves of the plant are cut close to the bole and stacked in bundles made up of 30 leaves (Fig. 1). These are then 

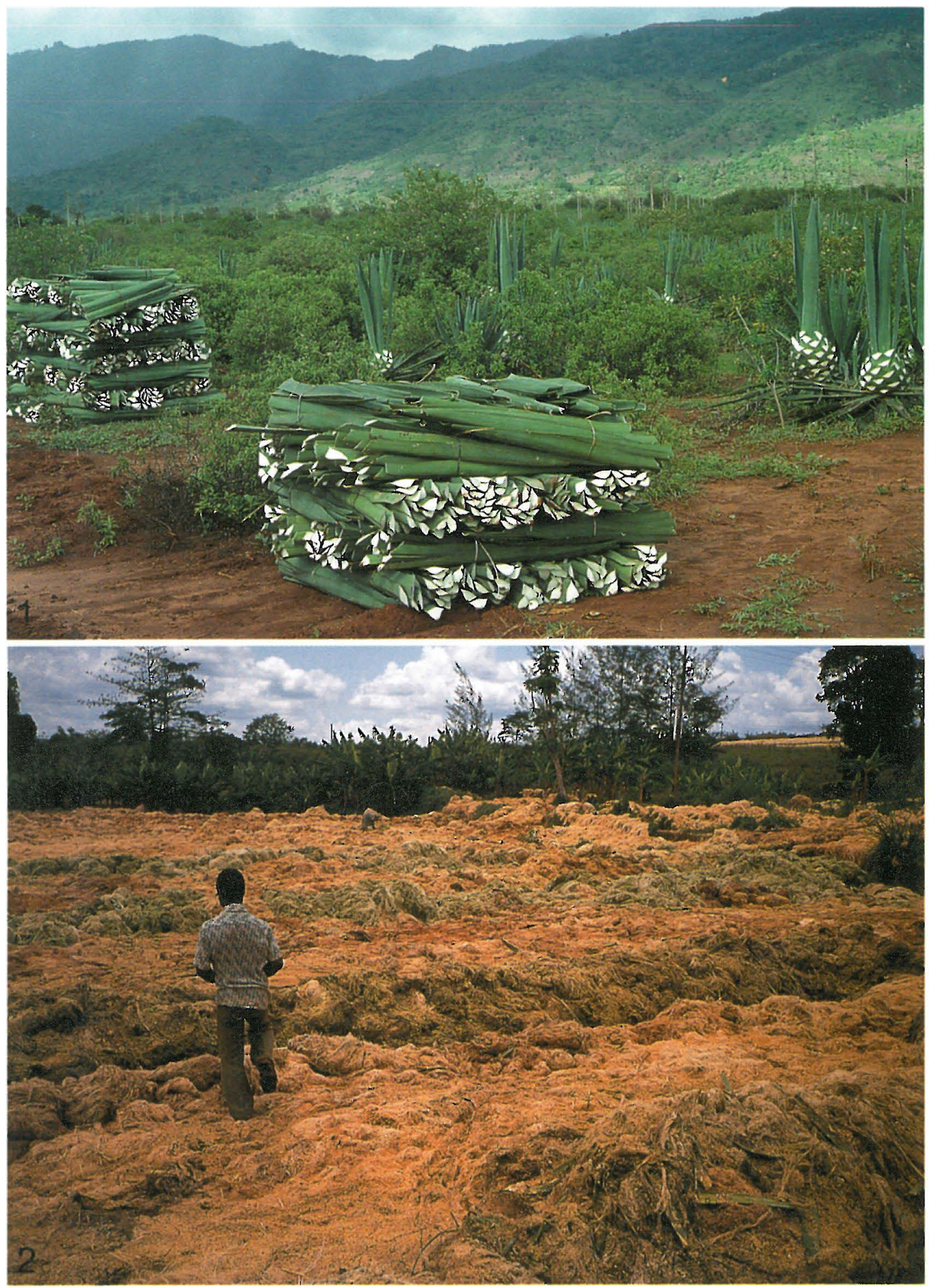

Figs. 1-2. Sisal production in Tanzania. - 1: Sisal plantation with cut sisal leaves waiting for transport to a factory. 2: Sisal waste compost of the Kitisa Sisal Estate in Muheza in Tanga District. 

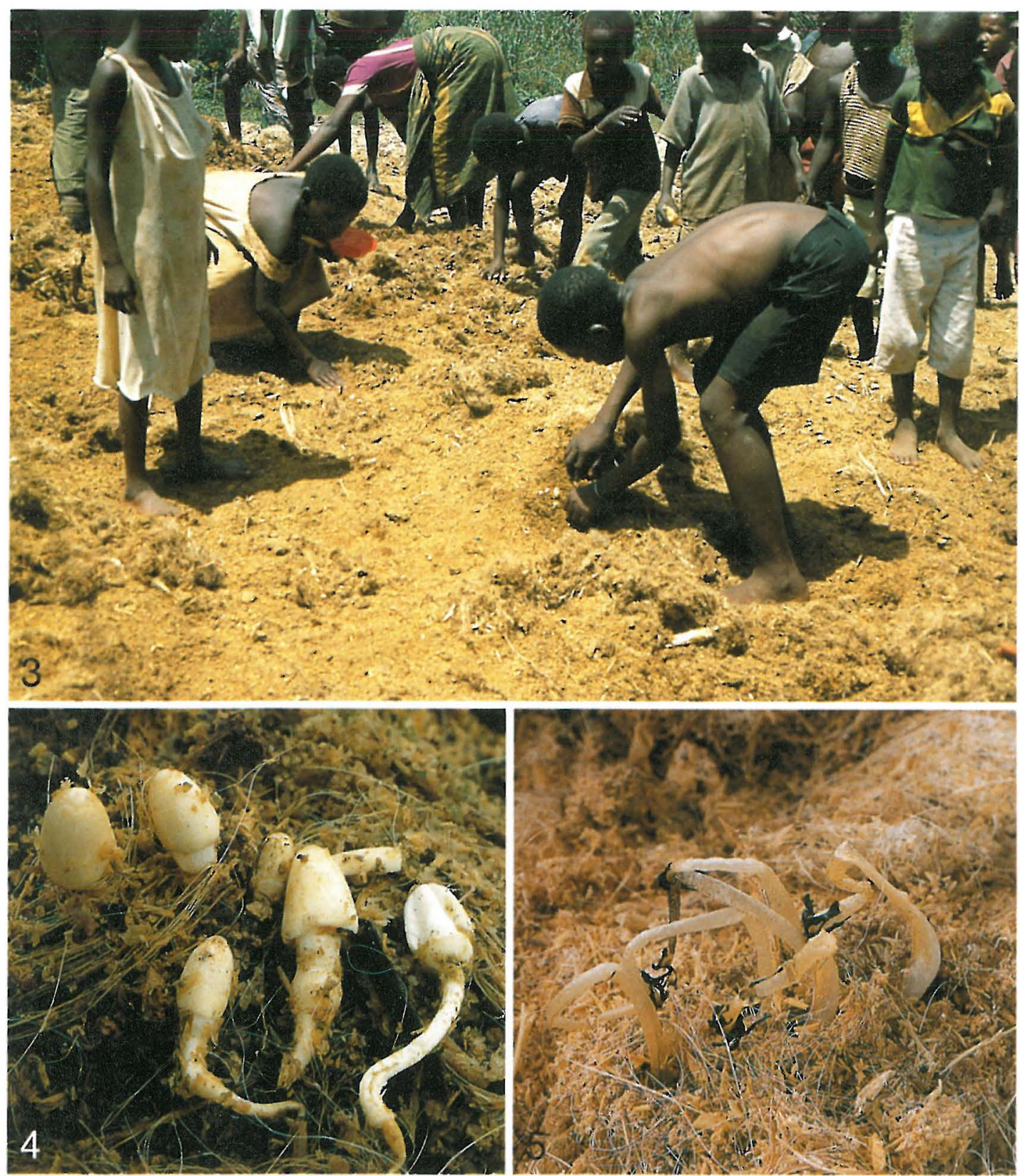

Figs. 3-5. Mushroom foray to waste dump of Kwamduru Sisal Estate near Korogwe in Lushoto District. - 3: Boy on the right and girl on the left have dug out small white fruit bodies of an ink cap. - 4: Young immature fruit bodies of the ink cap, favoured edible mushrooms (specimen No. 979). - 5: After reaching surface of compost fruit bodies deteriorate very quickly. 
taken to the factory for decortication. The leaves contain milk latex and deteriorate very fast; as they have to be processed within one to two days, the factory is usually centrally situated.

Untreated water is used in cleaning the fibres by means of the factory machinery. Sisal fibre is dried for a day and then hung in the sun to dry further and bleach white. The waste effluent from the decorticator is conveyed down wooden flumes to a big waste dump (Fig. 2). Fresh sisal waste is acidic, with $\mathrm{pH}$ values $4.8-5.2$ (Lock 1969). The dump never gets a chance to drain as supersaturated waste material is continually added to the surface. The waste decomposes very quickly and provides growth conditions for fungi.

\section{The growing sites of the sisal ink cap}

We visited three sisal plantations, viz. Tanga Province: Tanga District, Kitisa Sisal Estate; Tanga Province: Lushoto District, Kwamduru Sisal Estate; Eastern Province: Morogoro District, Kingolwira Sisal Estate (collecting localities according to Polhill 1988).

In every plantation we were taken to the back yard of the sisal factory where a big dump of decomposing sisal waste was to be seen (Fig. 2). That part of the giant compost where the sisal processing remnants had just been conveyed was bright green, the older part was pale greyish. When we inquired about the mushrooms, our guide, with the assistance of many children began to dig up the older part of the compost (Fig. 3). Their experience allowed them to find the mushrooms immediately. They turned out to be hypogeous adolescent basidiomes of a Coprinus (Fig. 4). A conspicuous feature of these fruit bodies is a bulbous stipe and a long thick pseudorrhiza. It is easy to conclude that with this pseudorrhiza the fruit body forces its way to the surface through the ever-growing waste pile. In every estate the composts felt hot, but we could not measure the temperature with the type of thermometer we had. The air temperature in the afternoon was $34-36^{\circ} \mathrm{C}$ in the shade.

A video showing these Coprinus mushrooms picked has been prepared (Härkönen \& Härkönen 1992).

\section{Common names}

We asked for any vernacular names for this mushroom which were used by the repre- sentatives of Bondei, Nyamwezi and Luguru tribes, each of which has a language of its own. All gave the name in the official language Swahili as "Uyoga wa mataka" or "Uyoga wa takataka". Both mean "a compost mushroom".

\section{The use of the ink cap}

We interviewed workers of the three sisal factories. The uses of this ink cap are the same in all the areas. The following report is compiled from the information obtained from the three sites:

The collecting of the mushroom has not been restricted. Everybody from the village is allowed to come to the compost. The pickers are usually relatives of the workers, most often women and children. Some children also pick mushrooms to sell to neighbouring households. In the workers' families mushrooms are usually eaten two to three times a week, but people who have scanty sources of meat or vegetables may eat them daily.

These mushrooms can be found all the year round, including the dry season. The sisal wastes are ready to produce mushrooms two to three weeks after sisal has been spread on the ground. The best time to collect the mushrooms is the morning hours or early evening. The collectors must dig into the sisal wastes to get fresh mushrooms. Those mushrooms which grow out of the wastes in fresh air turn black and are not good for consumption (Fig. 5).

People consider these mushrooms very tasty, but they are so perishable that they must be used within six hours after picking. They are prepared for food in the same way as other mushrooms: washed, cut into pieces and boiled in water or oil. Some people use both the caps and pseudorrhizas, some use only the caps.

\section{Identity of the sisal ink cap}

The fresh characters of the fruit bodies were documented soon after collection, and then the specimens were dried in a field drier heated with kerosene lamps.

The specimens were identified as Coprinus cinereus (Schaeffer: Fr.) S.F. Gray (e.g. Orton \& Watling 1979). The synonymy of the species is somewhat confusing, the oldest name $C$. fimetarius (L.) Fr. being much used. No type specimen for either of them has been chosen, but 
the concept of $C$. cinereus is based on a plate by Schaeffer (1762) (see Gray 1821). Our specimens agree with the fruit bodies illustrated in his water-colour plate in all respects other than the pseudorrhizas, which are lacking in his pictures. Above all, the blue colour of the mature basidiocarps in the plate corresponds to our material. The species is illustrated also in several other old colour plates. One by Bresadola (1931), under the name Coprinus fimetarius, has a bulbous base and a pseudorrhiza which fits rather well with our specimen. In Cooke (1881) the plate of "Coprinus fimetarius var. macrorhizus" shows prominent pseudorrhizas as in our specimens. Its spores, however, are larger and have a shape different from that of our material. C. macrorhizus (Pers.: Fr.) Rea has also been recognized at the species level (Rea 1922). Rea indicates decaying vegetable matter as a habitat of the species, corresponding to the material on which the fruit bodies grew in Tanzania. Interfertility experiments by Kemp (1975) indicate, however, that $C$. macrorhizus is conspecific with C. cinereus. Kemp (1985) emphasizes that no new taxa of Coprinus should be described without crossability tests.

According to Dr. Roy Watling (in litt.) our fungus does not fit well the European collections of $C$. cinereus, and he proposes mating tests for checking. Dr. R.F.O. Kemp has tried to cultivate our specimens but the spores were, however, nonviable, perhaps because the specimens were dried with kerosene lamps and later frozen for insect control.

Because the identity of the Tanzanian sisal ink cap is somewhat uncertain, we call it Coprinus cinereus sensu lato. In any case it is a member of Coprinus sect. Lanatuli. Obviously the long pseudorrhiza is not a constant character, but an adaptation to growing in continuously accumulating heaps of decaying plant material. Kher et al. (1992) have shown experimentally that in stems of Coprinus cinereus there is a very efficient mechanism of gravitropism. With that mechanism it is able to push its caps even out of the sisal compost. Some other minor differences observed between our specimens and Coprinus cinereus are not sufficient for distinguishing a new species without crossability tests. Singer (1975) states that "Coprinus belongs to those agaric genera where the average area of species is relatively large so that many representatives of "exotic" floras may be expected to exist also in
Europe and North America." If we later can import viable spores from Tanzania, we will return to the subject.

\section{Description of the Tanzanian material of Coprinus cinereus s.l.}

The following description is based on material collected from the three sisal estates mentioned above. The representative herbarium specimens (Saarimäki et al. 979, 983, 1146) are deposited in the Botanical Museum of the University of Helsinki $(\mathrm{H})$ and the Botanical Museum of the University of Dar es Salaam (DSM).

\section{Macroscopical characters from fresh material} - Figs. 3-7

Cap at first egg-shaped to elongate, then campanulate, $15-40 \mathrm{~mm}$ high and $10-30 \mathrm{~mm}$ wide, finally flattened into a thin, ruptured and revolute plate impossible to measure. Colour at first creamy white and then changing into bluish grey (in dried herbarium specimens light buff). The surface at first silky tomentose, later smooth, densely striate, sometimes with small evanescent scaly remnants of veil. At the top of the cap a lighter plate, which becomes more prominent when the fruit body gets older. Gills thin and crowded, at first white, then bluish grey, at last black, up to $4 \mathrm{~mm}$ broad, edge smooth. Stem slightly tomentose to silky, white, in young fruit bodies inside the cap equal, and just under it bulbous and rooting. No ring, but sometimes evanescent veil remnants. Towards maturity the stem grows from the upper side of the swelling and becomes hollow. The equal part of the stem 2-6 $\mathrm{mm}$ in diameter, the bulb $2-17 \mathrm{~mm}$ wide. The tapering pseudorrhiza most often $4-6 \mathrm{~cm}$ long, but sometimes much longer. Flesh thin, brittle, watery white, turning bluish when cut. Taste absolutely mild. Smell, while young and white, none, but becoming strong and sweet like caramel when older and having the bluish tint.

Microscopical characters from dried material in Melzer's reagent and Cotton Blue - Figs. 8-13

Spores date-brown, ovoid, smooth with a central germ pore 8-9.8-12 x 6-6.8-8.5 $\mu \mathrm{m}$. Basidia 4spored, trimorphic, from club-shaped to short cylindrical with or without slightly inflated base, 20-30 x 9-12 $\mu \mathrm{m}$. Basidioles ovoid or barrel- 

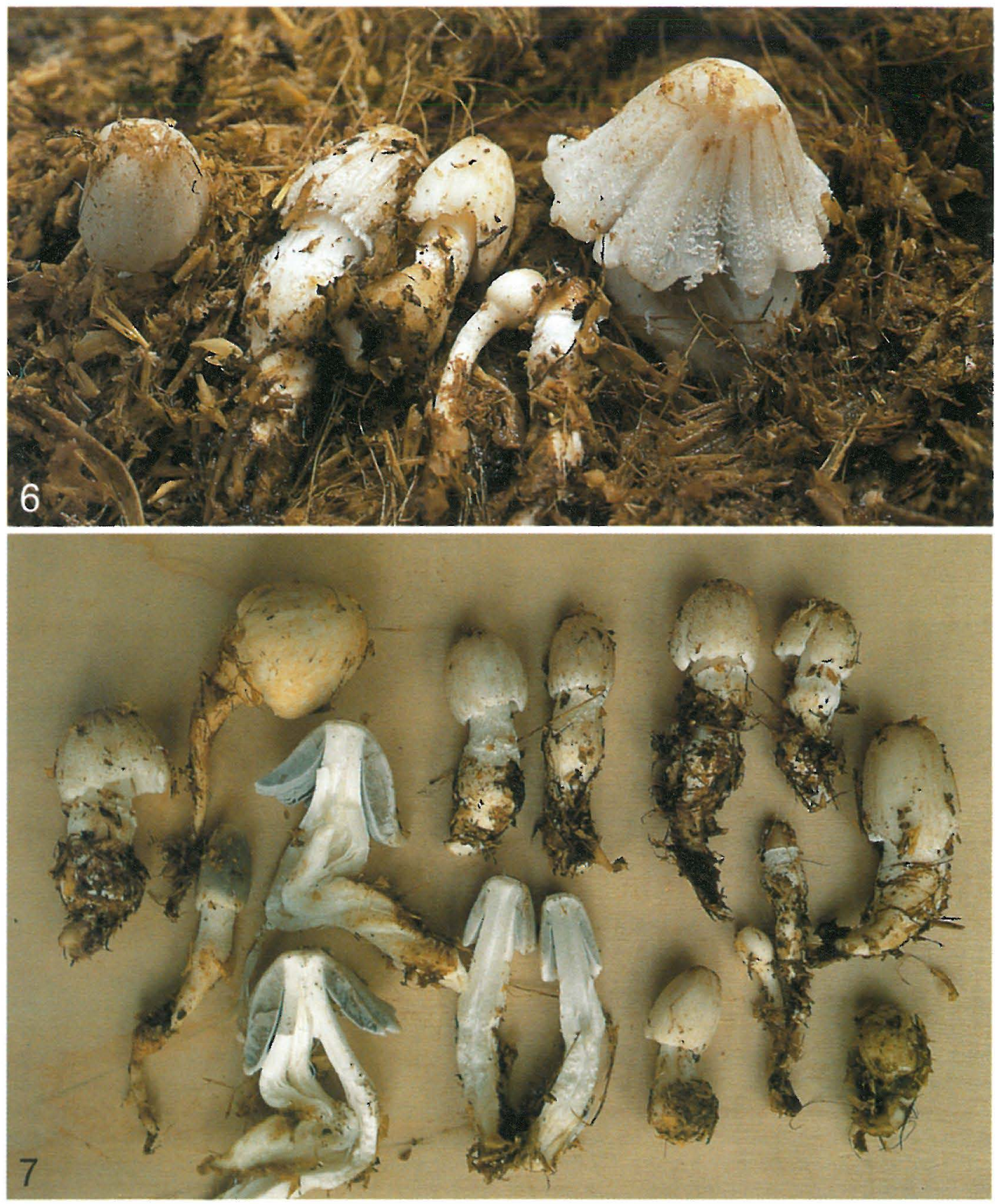

Figs. 6-7. Specimen No. 1146 from Kingolwira Sisal Estate in Morogoro. - 6: Fruit bodies in natural habitat. On the campanulate cap of the largest, evanescent scaly remnants of veil seen. - 7: Selection of fruitbodies. Note bluish tint of split ones. 

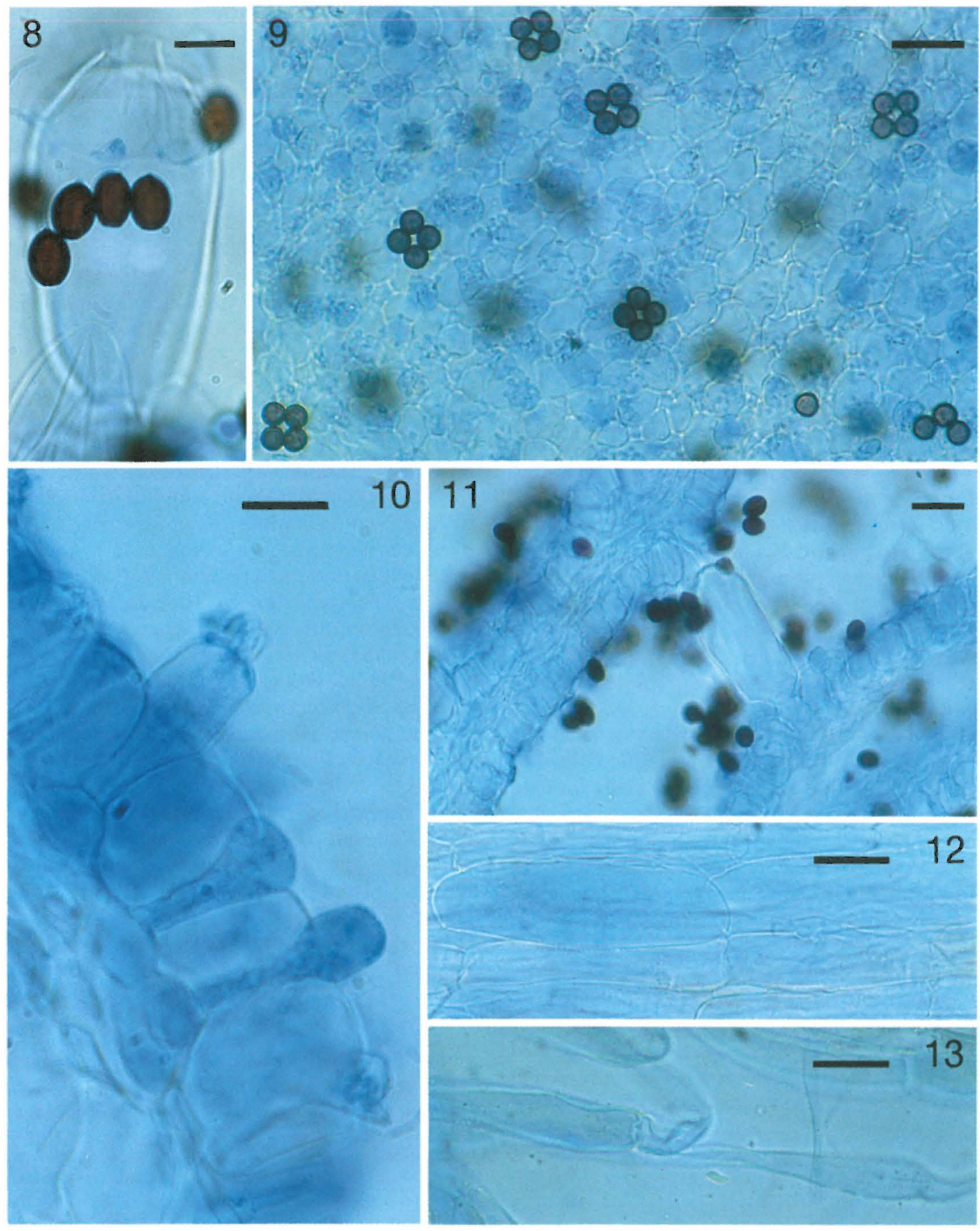

Figs. 8-13. Microscopical details of Coprinus cinereus s.1. Bar in Figs. 8, 10, 12, $13=10 \mu \mathrm{m}$; in Figs. 9, $11=20 \mu \mathrm{m}$. 8: Lateral view of spores against a facial cystidium (No. 983). - 9: Face-view of gill-surface (No. 979). Blue basidia separated by lighter sterile cells, basidioles. Spores with central germ-pores hanging as tetrades from some basidia. - 10: Young basidia separated by barrel-shaped sterile cells (No. 979). - 11: Facial cystidium separating two adjacent gills (No. 983). - 12: Cylindric cells of cap cuticle (No. 1146). — 13: Cells of veil, constricted at one end (No. 983). 
shaped, $18-20 \times 8-12 \mu \mathrm{m}$. Facial cystidia ellipsoid, 40-100 × 25-60 $\mu \mathrm{m}$. Marginal cystidia globose to pyriform, $30-40 \times 16-28 \mu \mathrm{m}$. Cap cuticle of radially arranged, cylindrical inflated cells 5-12 um wide. Veil remnants of thinner cells than those of cuticle and inflated only at one end.

The present specimens differ from the description of $C$. cinereus given by Orton and Watling (1979) clearly in the spore shape, which is wider in the Tanzanian material. The very obvious character for our material, the bluish colour of the maturing fruit bodies, is not mentioned in the description of $C$. cinereus.

\section{Edibility of Coprinus cinereus}

We have checked edibility notes in some European mushroom guides (e.g. Michael et al. 1981, Buczacki 1989), and C. cinereus is usually considered inedible. In Finland, Rautavaara (1947) supposes it might be edible, but because of its rapid deterioration it would have no practical value. In Japan, it is considered edible when young (Imazeki et al. 1988). According to Chandra (1989), C. cinereus is edible while the fruit bodies are young and unripe, and it can be cultivated on dry straw mixed with fertilizer. Singer (1986) states that it is impossible to produce Coprinus species commercially for food because of the difficulty of transport before they are "inky". According to him several species are, however, harvested by amateurs as young, $C$. cinereus being one of these species. Incidentally, in the British Isles packs of Coprinus comatus for home growing are on sale and yield reasonable results (Watling in litt.).

Kurtzman (1978) has made mass culture experiments with $C$. cinereus (using the name $C$. fimetarius). He mentions that it is often assumed that all members of the genus Coprinus are far too ephemeral to be handled commercially. One of his isolates, however, can be preserved for more than three days with good refrigeration, or it may be canned or dried. Its flavour is excellent and it grows to a rather uniform size which is suitable for both canning and for visual appeal in fancy dishes. Its nutritional value is good, and it contains nearly $30 \%$ protein.
In Tanzanian sisal waste composts, all the conditions which Kurtzman found to be suitable for the cultivation of $C$. cinereus seem to be present naturally. Kurtzman used a compost of straw and water, and calcium nitrate as fertilizer. The remnants of living sisal leaves do not, however, need extra fertilizing. In Kurtzman's experiments the mushrooms thrived at $35^{\circ} \mathrm{C}-40^{\circ} \mathrm{C}$, and it was important to maintain relative humidity in excess of $80 \%$. Hot climate and continuous addition of watery waste material as well as heating by microbial activity maintain these same conditions in the sisal waste heaps.

\section{Discussion}

Coprinus cinereus s.l. is no doubt a significant side product of sisal factories, adding a good amount of protein to the diet of the workers on the sisal plantations. With better understanding of its growth conditions, its productivity might even be increased. Its commercial value is restricted by the rapid deterioration of the fruit bodies. This mushroom species cannot be preserved in the typical Tanzanian way, by drying in the sun. Before trying to expand its use outside the close vicinity of the factories, new methods of preserving should be developed.

The people we interviewed did not furnish any vernacular name for this mushroom. This may be because of the introduced nature of the sisal plant. The Swahili names "Uyoga wa takataka" and "Uyoga wa mataka" mean a mushroom growing on any kind of waste material. To distinguish it from other edible mushrooms growing on dead plant material, a better name for it would be "Uyoga wa taka za mkonge", "A sisal-compost mushroom".

Acknowledgements. We wish to thank the directors of the Kitisa, Kwamduru and Kingolwira Sisal Estates for showing us through the sisal factories and allowing us to interview their employees. Dr. Roy Watling (Edinburgh) and Mr. Paavo Höijer (Porvoo, Finland), deserve thanks for their help in the identification of our fungus specimens, and Dr. Roger Kemp, Edinburgh, for the cultivation trials. Mr. Yu-Cheng Dai, M.Sc., Beijing, receives thanks for the translation of Japanese. We are grateful to Professor Teuvo Ahti for his critical reading of the manuscript. Dr. Carol Norris revised the English. The research was financed by the Finnish International Development Agency (FINNIDA). 


\section{References}

Bresadola, J. 1931: Iconographia Mycologica 17. — 801850 pls. Milan.

Buczacki, S. 1989: Fungi of Britain and Europe. - 320 pp. Collins, London.

Chandra, A. 1989: Elsevier's dictionary of edible mushrooms. - 259 pp. Elsevier, Amsterdam.

Cooke, M.C. 1881: Illustrations of British fungi (Hymenomycetes) I. - Williams and Norgate, London.

FAO 1991: Yearbook Trade 1990. - Statistics Ser. 102(44): 1-379.

Gray, S.F. 1821: A natural arrangement of British plants I. - 824 pp. Baldwin, Cradock, and Joy, London.

Härkönen, M. 1992: Wild mushrooms, a delicacy in Tanzania. - Univ. Helsingiensis 12:29-31.

Härkönen, M. \& Härkönen, K. 1992: A sisal mushroom. A video. - Univ. of Helsinki, Dept. of Botany \& Audiovisual Centre: $7 \mathrm{~min}$.

Härkönen, M., Saarimäki, T. \& Mwasumbi, L. 1993a: Setting up a research project on Tanzanian mushrooms and their use. - Proc. XIII AETFAT Congress, Zomba, Malawi (in press).

Härkönen, M., Saarimäki, T., Mwasumbi, L. \& Niemelä, T. 1993b: Collecting of Tanzanian mushroom heritage as a developmental cooperation between the universities of Helsinki and Dar es Salaam. - Aquilo, Ser. Bot. (in press).

Härkönen, M., Buyck, B., Saarimäki, T. \& Mwasumbi, L. 1993c: Tanzanian mushrooms and their uses: I. Russula. - Karstenia 33:11-50.

Imazeki, R., Otani, Y. \& Hongo, T. 1988: Fungi of Japan. (In Japanese.) - 624 pp. Yama-Kei Publishers, Tokyo.

Kemp, R.F.O. 1975: Breeding biology of Coprinus species in the section Lanatuli. - Trans. British Mycol. Soc. 65:375-388.
Kemp, R.F.O. 1985: Do fungal species really exist? A study of basidiomycete species with special reference to those in Coprinus section Lanatuli. - Bull. British Mycol. Soc. 19:34-39.

Kher, K., Greening, J., Hatton, J., Frazer, L., Moore, D. 1992: Kinetics and mechanics of stem gravitropism in Coprinus cinereus. - Mycol. Res. 96:817-824.

Kurtzman, R.H. 1978: Coprinus fimetarius. - In: Chang, S.T. \& Hayes, W.A. (eds.), The biology and cultivation of edible mushrooms: 393-408. Academic Press, London.

Lock, G.W. 1969: Sisal, thirty years sisal research in Tanzania. - 365 pp. Longmans, London.

Michael, E., Hennig, B. \& Kreisel, H. 1981: Handbuch für Pilzfreunde 4. $-472 \mathrm{pp}$. Fischer, Jena.

Orton, P.D. \& Watling, R. 1979: Coprinaceae Part 1: Coprinus. - In: Henderson, D.M., Orton, P.D. \& Watling, R. (eds.), British fungus flora 2. $149 \mathrm{pp}$. HMSO, Edinburgh.

Polhill, D. 1988: Flora of East Tropical Africa. Index of collecting localities. - 398 pp. Royal Botanical Gardens, Kew.

Rautavaara, T. 1947: Suomen sienisato. (Summary: Studies on the mushrooms crop in Finland and its utilization.) - 534 pp. WSOY, Porvoo \& Helsinki.

Rea, C. 1922: British basidiomycetae. — 799 pp. Cambridge University Press, London.

Schaeffer, J.C. 1762: Fungorum qui in Bavaria et Palatinatu circa Ratisbonam nascuntur icones nativis coloribus expressae I. - 1-100 pls. Zunkel, Ratisbonae.

Singer, R. 1975: The Agaricales in modern taxonomy. 912 pp. Cramer, Vaduz.

Singer, R. 1986: The Agaricales in modern taxonomy. 981 pp. Koeltz, Koenigstein.

Received on 28 November 1992 